\title{
PRESENTATION OF THE RESULTS FOR DEUTERIUM RETENTION AND THERMAL RELEASE IN A NEW TYPE OF LOW ACTIVATION FERRITIC- -MARTENSITIC STEEL EUROFER
}

\author{
Sanja Lj. Korica \\ University Union - Nikola Tesla, \\ Faculty for Ecology and Environmental Protection, \\ Belgrade, Republic of Serbia, \\ e-mail: koricasanja@gmail.com, \\ ORCID iD: (Dhttp://orcid.org/0000-0002-7915-9430
}

DOI: 10.5937/vojtehg64-9327

\author{
FIELD: Materials \\ ARTICLE TYPE: Original Scientific Paper \\ ARTICLE LANGUAGE: English
}

\begin{abstract}
:
This work presents the results of the investigation into deuterium retention and thermal release in low activation ferritic-martensitic steel EUROFER and its main components, $\mathrm{Fe}$ and $\mathrm{Cr}$, using ion implantation, nuclear reaction depth profiling and the thermal desorption spectrometry technique. The samples were exposed to deuterium ECR plasma of $6.5 \times 10^{24} \mathrm{Dm}^{-2}$ fluence. Our NRA results show that, at $300 \mathrm{~K}$, most of deuterium is trapped in the near-surface region. A part of the implanted deuterium diffuses into the bulk and is trapped by defects beyond the implantation range. The results of the TDS measurement of the $\mathrm{Cr}$ sample confirm the formation of an ordered Cr-hydride phase.
\end{abstract}

Key words: nuclear reactor materials, radiation effects, diffusion, nuclear resonances.

ACKNOWLEDGMENT: Acknowledged is the support to this work provided by the DAAD Organization and the Ministry of Education, Science and Technological Development of Serbia through Project in Physics and Chemistry with Ion Beams, no. III45006. 


\section{Introduction}

Reduced activation ferritic-martensitic (RAFM) steels are presently the leading candidate materials for the first wall and breeding blanket structural application for ITER and future power plants. This class of steels has been selected mainly because of their improved radiation resistance and the potential of reduced activation. These materials have been developed by replacing alloying elements like $\mathrm{Mo}, \mathrm{Nb}$ and $\mathrm{Ni}$ in the commercial martensitic steels by other elements which exhibit faster decay of induced radioactivity such as Ta, W and V (Kohyama, 1996, pp.138-147). They also show excellent mechanical and thermo-physical properties (Lindau, 2005, pp.989-996) and swelling resistance (Baluc, 2007, pp.33-41).

EUROFER'97 is the RAFM steel developed for the requirements of the European fusion technology program (Gasparoto, 2003, pp.129137). Its chemical composition has been designed to achieve good activation properties and irradiation resistance (Van der Schaaf, 2003, pp.197-203), (Tavassoli, 2004, pp.257-262). It is expected that $\mathrm{Fe}$ and $\mathrm{Cr}$, as its main components, will have the most impact on its overall properties. As a structural material for the future fusion application, EUROFER will be exposed to intense fluxes of energetic hydrogen isotope ions and neutrals as products of nuclear reactions (Yao, 2005, pp.1285-1291). Retention and further transport of the hydrogen isotopes will have implications on material stability, environmental safety and recycling to the plasma. Hydrogen transport and trapping in EUROFER have been recently studied by means of the gas evolution permeation technique (Esteban, 2007, pp.473-477) assuming that martensitic steel is close to a bcc structure where $\mathrm{H}$ occupies only tetrahedral interstitial positions (Seeger, 1976, pp.137-138).

An experiment has shown that the $\mathrm{H}$ transport is limited to diffusive phenomena rather than surface effects, though a complete lack of surface effects cannot be proven. Activation energy $\left(E_{a}\right)$, found to be close to $59 \mathrm{~kJ} / \mathrm{mol}$, corresponds to high angle grain boundaries (Esteban, 2000, pp.34-41). This indicates that the governing cause of the $\mathrm{H}$ trapping in EUROFER may be grain boundaries and/or fine martensitic laths, characteristic for this type of steel.

This paper presents a study on the retention and thermal release of deuterium in $\mathrm{Fe}, \mathrm{Cr}$ and EUROFER irradiated with $\mathrm{D}$ ions by means of ion beam analysis techniques and thermal desorption spectroscopy (TDS). 


\section{Experimental details}

Polycrystalline $\mathrm{Fe}$ and $\mathrm{Cr}$ foils of quoted purity $99.99 \%, 0.5 \mathrm{~mm}$ in thickness delivered by Goodfellow and EUROFER steel foil, $1 \mathrm{~mm}$ in thickness, were used in this work. Note that the main alloying elements of the EUROFER are $\mathrm{Fe}$ and 9.2 at.\% $\mathrm{Cr}$. Rectangular-shape samples $12 \times 15 \mathrm{~mm}$ in size were cut from the foils and then mechanically polished prior the measurements.

The samples were exposed to deuterium plasma in an electroncyclotron-resonance source PlaQ in IPP, Garching (Manhard, 2011, pp.015-010). Thus source is equipped with a biased sample holder and is well suited for the implantation of deuterium ions. A PlaQ experiment consists of a stainless steel chamber where plasma is confined in a cylindrical steel mesh cage with a height of $15 \mathrm{~cm}$ and a diameter of 14 $\mathrm{cm}$. A plasma beam consisting mainly of $\mathrm{D}_{3}{ }^{+}$ions reaches a sample holder through a circular aperture of the steel plate placed at the bottom of the cage. The whole sample is homogeneously irradiated. A typical achievable deuteron flux is in the range $10^{19}$ to $10^{20} \mathrm{D} \mathrm{m}^{-2} \mathrm{~s}^{-1}$. Achievable energies range from several $\mathrm{keV}$ up to $200 \mathrm{keV}$ per deuteron.

The surface morphology of the samples subjected to the $D$ plasma exposures was examined using scanning electron microscopy.

Deuterium depth profiles were determined using the nuclear reaction analysis technique (NRA) at a Tandem Accelerator in IPP, Garching. The analysis was carried out by directing a ${ }^{3} \mathrm{He}$ beam normally on the samples and measuring the proton yield from the induced nuclear reaction $D\left({ }^{3} \mathrm{He}, p\right)^{4} \mathrm{He}$ as a function of an incident ${ }^{3} \mathrm{He}$ energy beam. Series of seven different ${ }^{3} \mathrm{He}$ energies were used in the range from 0.5 to 4.5 MeV, following the reaction cross section which was obtained from the literature (Alimov, 2005, pp.169-175) and which exhibits a maximum at around $0.65 \mathrm{MeV}$. The computer program NRADC was used for the analysis of the data (Schmid, 2012, pp.64-71). Here, a deuterium concentration profile was extracted from the proton yield using an iterative deconvolution procedure.

Protons from the nuclear reaction $\mathrm{D}\left({ }^{3} \mathrm{He}, \mathrm{p}\right)^{4} \mathrm{He}$ were counted with a Si surface barrier detector which subtended a solid angle of $0.106 \mathrm{Sr}$ at $150^{\circ}$ from the incident-beam direction. This detector was covered with $0.4 \mathrm{~mm}$ of $\mathrm{Al}$ foil to range out unwanted charged particles. The detector acceptance angle was calibrated by Rutherforf backscattering from a C film on a Be substrate, with the intervening Al foil removed.

Thermal desorption spectroscopy (TDS) measurements were performed with a custom built set-up in INN Vinča, Belgrade, consisting of a quartz tube placed inside the furnace. The samples were outgassed at $293 \mathrm{~K}$ under $1.9 \times 10^{-8} \mathrm{~Pa}$ and subsequently subjected to a linear 
heating rate of $20 \mathrm{~K} / \mathrm{min}$ to $1273 \mathrm{~K}$ under high vacuum. The partial pressures of $\mathrm{H}_{2}, \mathrm{H}_{2} \mathrm{O}$ and $\mathrm{D}_{2}$ released were monitored with a quadrupole mass spectrometer (Extorr 3000).

\section{Results and Discussion}

\section{$D$ retention in $\mathrm{Fe}$}

In the first set of experiments, two Fe samples were used: the first Fe sample as prepared, i.e., mechanically polished, and the second one additionally annealed at $1120 \mathrm{~K}$ for $1 \mathrm{~h}$ in vacuum under $\sim 10^{-5} \mathrm{~Pa}$ to enlarge grains and remove the cold-work damage. The SEM micrographs of the samples show that in the case of the sample without previous heat treatment, no pronounced surface structures were observed. On the other hand, the microstructure of the annealed sample consists of anisotropically distributed grains of white boarders. The mean grain size observed by SEM was $50-100 \mu \mathrm{m}$.

After that, both samples were simultaneously exposed to deuterium plasma in PLAQ at room temperature. The energy of deuterium ions was $<5 \mathrm{keV} / \mathrm{D}$ and the irradiation flux was $5.6 \times 10^{19} \mathrm{Dm}^{2} \mathrm{~s}^{-1}$. The total ion fluence was $4 \times 10^{24} \mathrm{Dm}^{-2}$.

The calculations performed by the SRIM code (Ziegler, 2004, pp.1027-1036) indicate that this energy corresponds to the approximate deuterium penetration depth (projected range) of $400 \mathrm{~nm}$. A displacement damage (damage distribution profile) peak is located at 50 $\mathrm{nm}$ from the surface. The projected range of $D$ is increasing monotonically with increasing ion energy. Along its trajectory, ion is producing damage which can serve as trapping sites for deuterium. In most ion irradiations in $\mathrm{Fe}$, the damage region is usually within a few micrometers of the irradiated surface (Horton, 1981, pp.1343-1347). The defect structures significantly depend on the distance from the irradiated surface. However, a comparison to binding energies of deuterium to various traps in iron and ferritic-martensitic steels indicate that probably in both cases vacancies are the major traps (Forcey, 1990, pp. 357-363), (Pressouyre, 1979, pp.1571-1573).

Deuterium is highly mobile in Fe with a diffusion activation energy of $\sim 0.05 \mathrm{eV}$ and a room-temperature diffusivity of $\sim 10^{-9} \mathrm{~m}^{2} \mathrm{~s}^{-1}$.

Hydrogen diffusivity in iron and martensitic MANET II shows a pronounced dependence on gas pressure and a deviation from Arrhenius type temperature dependence at temperatures below $300^{\circ} \mathrm{C}$ (Wedig, 1997, pp.138-146). For the case of hydrogen transport and trapping in austenitic stainless steels, Langley (Langley, 1984, pp.622-628) 
proposed a two-region diffusion model where the solid is considered to consist of two components, a surface layer and a bulk material. In this model, the surface layer is characterized by a smaller diffusion coefficient than the bulk. This was confirmed by the measurements of Wilson and Baskes (Wilson, 1978, pp.291-297) on deuterium trapping in 316 stainless steels. Their desorption data showed that there are two dominant mechanisms: bull migration of mobile deuterium atoms with $0.6 \mathrm{eV}$ migration energy and release from near surface traps with a net detrapping energy of $\sim 0.9 \mathrm{eV}$. Here, the diffusivity was determined to be $\mathrm{D}_{0}=0.12 \mathrm{~cm}^{2} / \mathrm{s}$ and $\mathrm{E}_{\text {activ }}=0.61 \mathrm{eV}$.

After the plasma exposure, the concentration of $D$ in each sample was determined by the nuclear reaction analysis (NRA). The NRA results are shown in Figure1.

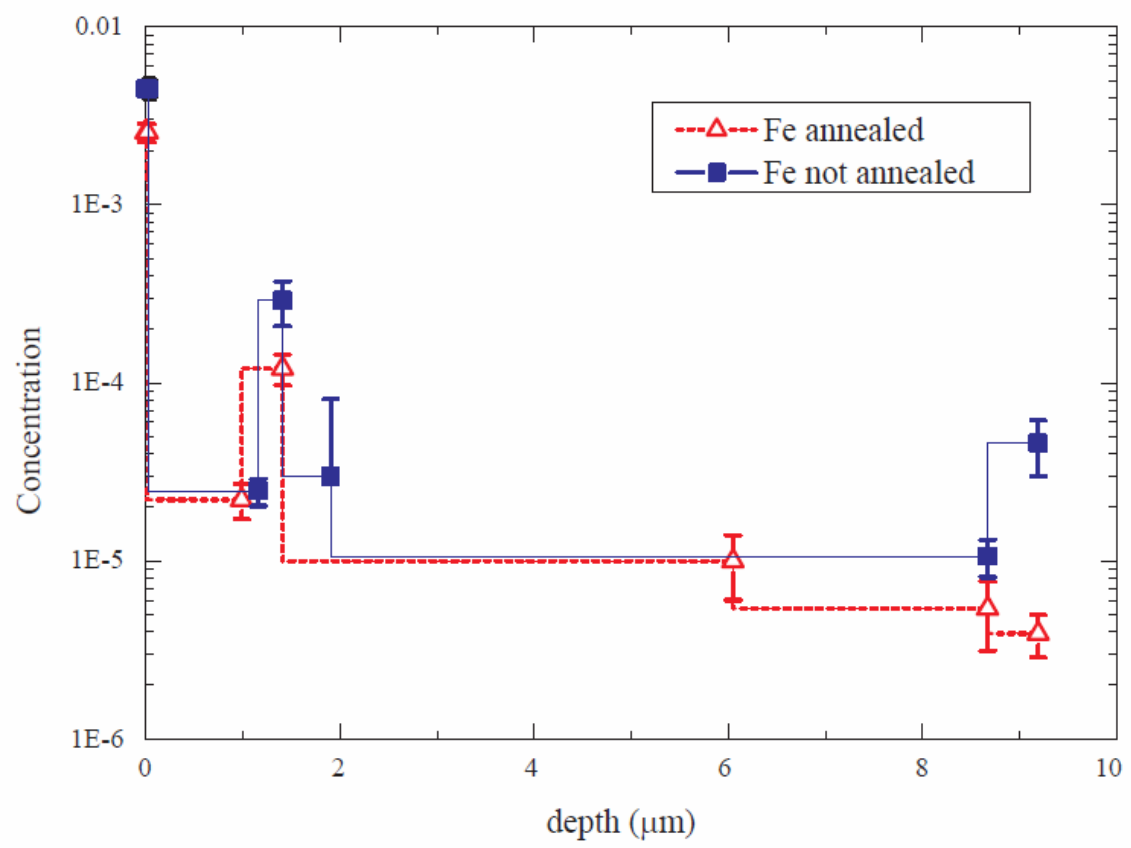

Figure 1 - Deuterium depth profile for the Fe samples exposed to deuterium plasma at $300 \mathrm{~K}$ to a fluence of $\mathrm{F}=4 \times 10^{24} \mathrm{Dm}^{-2}(-)$ not annealed and (----) annealed in vacuum at $1120 \mathrm{~K}$ for $1 \mathrm{~h}$

Slika 1 - Dubinski profil deuterijuma za uzorke Fe ozračene plazmom deuterijuma na $300 \mathrm{~K}$ i pri fluksu od $\mathrm{F}=4 \times 10^{24} \mathrm{Dm}^{-2}(-)$ nezagrevani i (----) zagrevani u vakuumu na $1120 \mathrm{~K}$ u trajanju od $1 \mathrm{~h}$

Puc. 1 - глубинный профиль дейтерия образца $\mathrm{Fe}$,

облучённый дейтериевой плазмой на $300 \mathrm{~K}$ и при флюенсе $\mathrm{F}=4 \times 10^{24} \mathrm{Dm}^{-2}(-)$ не разогретый и (----) разогретый в вакууме на 1120 К в течение 1 часа 
The depth profiles in the both samples are characterized by a very high concentration of deuterium in the near surface region, probably due to the trapping at the plasma irradiation induced defects. At depths above $1 \mu \mathrm{m}$, the concentration exponentially decreases due to the $D$ diffusion into the bulk. The only unusual feature is the increase of the concentration in the bulk which appears for both samples at around $1 \mu \mathrm{m}$ and will be discussed later in the text.

\section{$D$ retention in $\mathrm{Fe}, \mathrm{Cr}$ and EUROFER}

In the second set of measurements, five different samples were used:

- two Fe samples (one unprocessed and another additionally coated with a $130 \mathrm{~nm}$ thick Au layer on one side)

- two EUROFER samples (one unprocessed and another additionally coated with a $130 \mathrm{~nm}$ thick Au layer on one side)

- one Cr sample, as prepared

The reason for using Au coating is that a hydrogen barrier is planned to be placed between the plasma facing material and EUROFER which is planned to be used as the first wall in future fusion reactors. This barrier will prevent tritium transport and retention through the first wall. The study on alumina (Levchuk, 2004, pp.103-106) has shown that this material is a promising candidate for this purpose. It showed a significant decrease of the permeation flux compared to the bare material $\left(\sim 10^{3}\right.$ factor $)$ where surface effects seem to play an important role. With this experiment, we wanted to test $A u$ as a potential diffusion barrier for $D$ in a combination with EUROFER as a substrate. Similarly to the mentioned study, a very thin Au coating was used to prevent the neutron induced activation from $\mathrm{Au}$.

All samples were annealed at $873 \mathrm{~K}$ for $3 \mathrm{~h}$ in vacuum under $\sim 10^{-5} \mathrm{~Pa}$ to enlarge grains and remove the cold-work damage. SEM micrographs of the EUROFER and $\mathrm{Cr}$ samples show that Fe samples look basically the same as in the first measurement (the formation of a grain structure is observed after the annealing procedure). In the case of the EUROFER sample, the structure of the alloy did not change significantly after the heating procedure. In the case of the $\mathrm{Cr}$ sample, a network crack structure was observed before the annealing procedure. The microstructure of the annealed sample consists of additional anisotropically distributed grains. The mean grain size observed by SEM was $1 \mu \mathrm{m}$.

After that, all samples were exposed simultaneously to deuterium plasma in PLAQ at room temperature. The energy of deuterium ions was $38 \mathrm{keV} / \mathrm{D}$ and the irradiation flux was $9 \times 10^{19} \mathrm{Dm}^{-2} \mathrm{~s}^{-1}$. The total ion fluence was $6 \times 10^{24} \mathrm{Dm}^{-2}$. 
The calculations performed by the SRIM code indicate that this energy corresponds to the approximate deuterium penetration depth of $500 \mathrm{~nm}$ in Fe. A displacement damage peak is located at $300 \mathrm{~nm}$ from the surface. Deuterium trapping in stainless steel occurs in radiation induced damage sites (e.g., vacancies, interstitial loops, etc.), in voids, grain boundaries and impurities (Wilson, 1981, pp.453-463). The previous measurements indicate that two dominant radiation damage traps exist with binding energies of $\sim 0.1$ and $0.3 \mathrm{eV}$ (Bohdansky, 1980, pp.594-600).

After the plasma exposure in our experiment, the $D$ concentration in each sample was determined by means of the nuclear reaction analysis (NRA). Figure 2 gives the $D$ depth profile in the Fe samples. The depth profile is similar as in the first experiment except that an unusual stepstructure appears at a greater depth of $\sim 4 \mu \mathrm{m}$. This indicates the structure is not constant and is related to the energy of the injected ions.

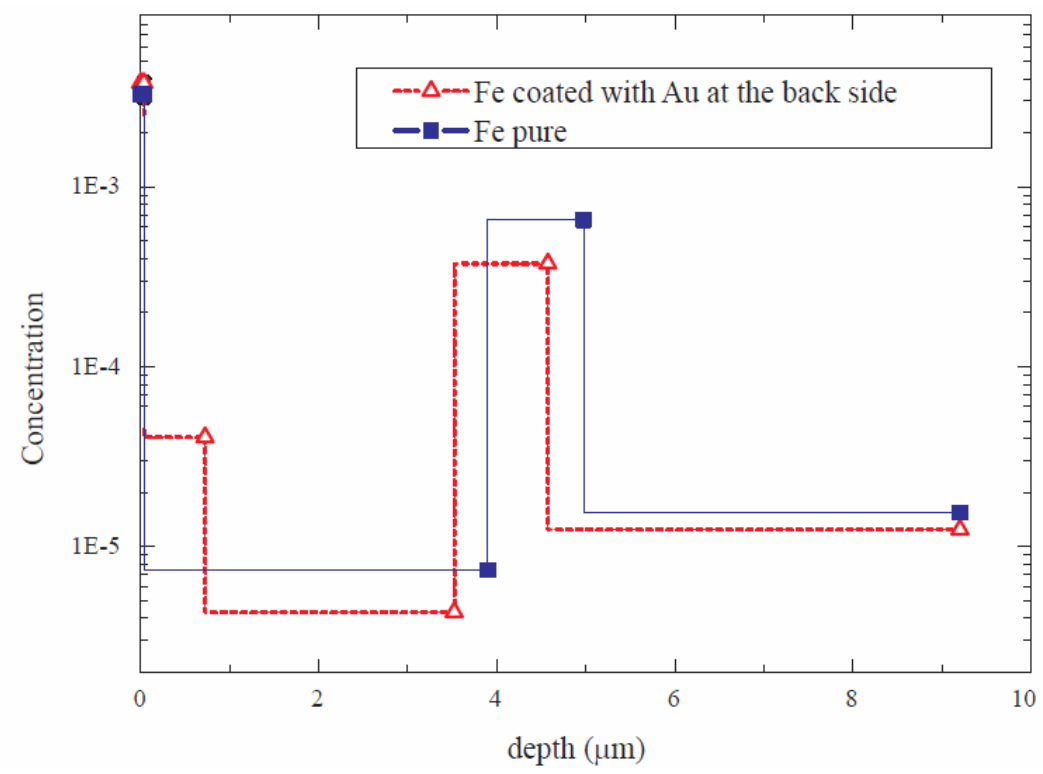

Figure 2 - Deuterium depth profile for the Fe samples annealed in vacuum at $873 \mathrm{~K}$ for $1 \mathrm{~h}$ and then exposed to deuterium plasma at $300 \mathrm{~K}$ to a fluence of $\mathrm{F}=6 \times 10^{24} \mathrm{Dm}^{-2}$

Slika 2 - Dubinski profil deuterijuma za uzorke Fe zagrevane u vakuumu na $873 \mathrm{~K}$

$\mathrm{u}$ trajanju od $1 \mathrm{~h}$, a zatim ozračene plazmom deuterijuma na $300 \mathrm{~K}$ pri fluksu

$$
\mathrm{F}=6 \times 10^{24} \mathrm{Dm}^{-2}
$$

Puc. 2 - глубинный профиль дейтерия образца $\mathrm{Fe}$, разогретый в вакууме на $873 \mathrm{~K}$ в течение 1 часа, а затем облученный дейтериевой плазмой на $300 К$ при фрлюенсе $\mathrm{F}=6 \times 10^{24} \mathrm{Dm}^{-2}$

Figure 3 and Figure 4 give the $D$ depth profile in the EUROFER and $\mathrm{Cr}$ samples. The depth profile of EUROFER shows a similar structure as in the case of the pure Fe samples except that the concentration is about 
two times higher than in Fe. The peculiar peak-like structure in the concentration profile of EUROFER probably comes from Fe as the main constituent of this steel. Our measurements are supported by the results of (Spitsyn, 2014, pp.561-567) who have performed a similar kind of measurements on the RUSFER (a Russian version of EUROFER). They have observed similar structures in the depth profiles measuring them for different temperature and energy series. They also showed that, by increasing the temperature, the concentration decreases and already at $200^{\circ}$ is below the sensitivity of the detector.

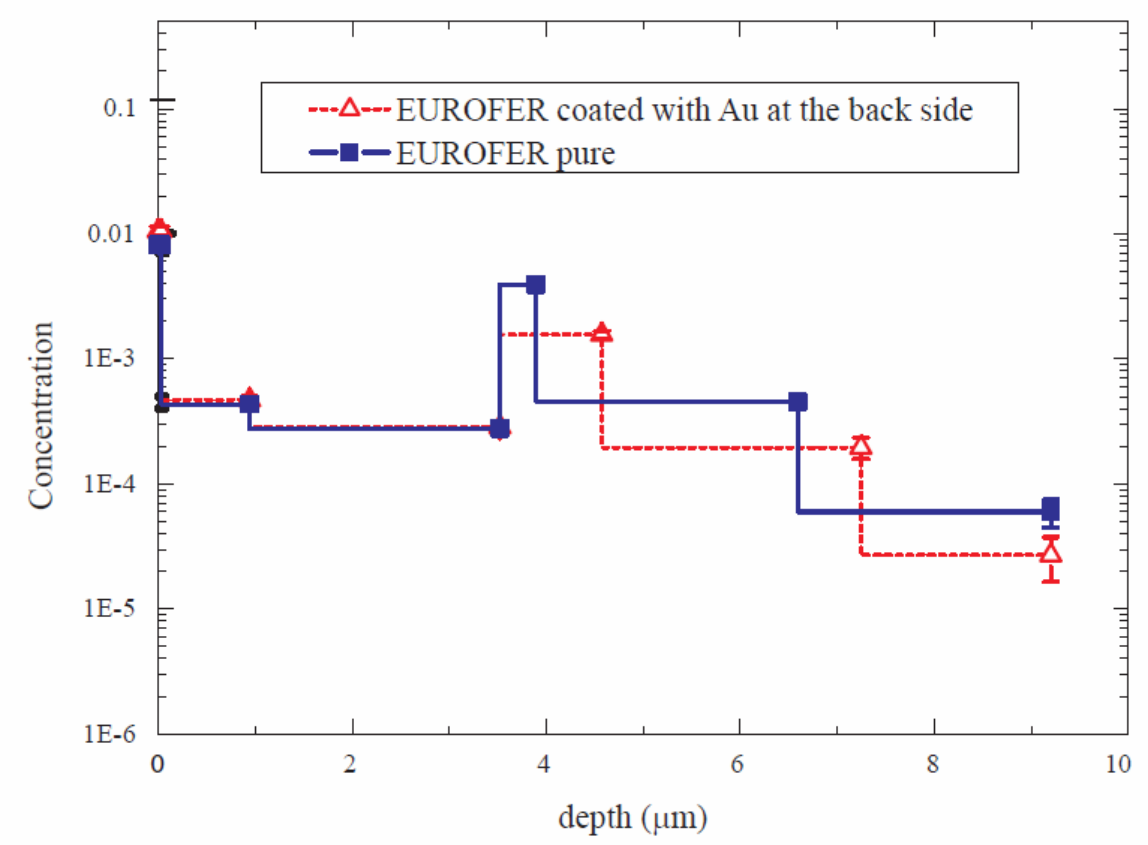

Figure 3 - Deuterium depth profile for the EUROFER samples annealed in vacuum at $873 \mathrm{~K}$ for $1 \mathrm{~h}$ and then exposed to deuterium plasma at RT to a fluence of $\mathrm{F}=6 \times 10^{24}$ $\mathrm{Dm}^{2}(-)$ not coated with $\mathrm{Au}$ and (---) coated with a $130 \mathrm{~nm}$ thick Au layer

Slika 3 - Dubinski profil deuterijuma za uzorke EUROFER-a zagrevane u vakuumu na $873 \mathrm{~K}$ u trajanju od $1 \mathrm{~h}$, a zatim ozračene plazmom deuterijuma na sobnoj temperaturi i fluksu $\mathrm{F}=6 \times 10^{24} \mathrm{Dm}^{-2}(-)$ neobloženi slojem Au i (---)obloženi slojem Au debljine $130 \mathrm{~nm}$ Puc. 3 - глубинный профиль дейтерия образцов EUROFER, разогретых в вакууме на 873 К в течение 1 часа, а затем облученных дейтериевой плазмой на комнатной температуре при флюенсе $\mathrm{F}=6 \times 10^{24} \mathrm{Dm}^{-2}(-)$ необлицованные Au i (---)облицованные Au coated толщиной $130 \mathrm{~nm}$

The $\mathrm{D}$ concentration profile in the $\mathrm{Cr}$ sample is characterized by a very high concentration peak in the near surface region (almost 10 magnitudes of order higher than in the pure Fe samples!) and the further 
exponential decay of the concentration in the bulk. This suggests that in the case of $\mathrm{Cr}$ there is probably the formation of the chromium hydride on the surface of the sample.

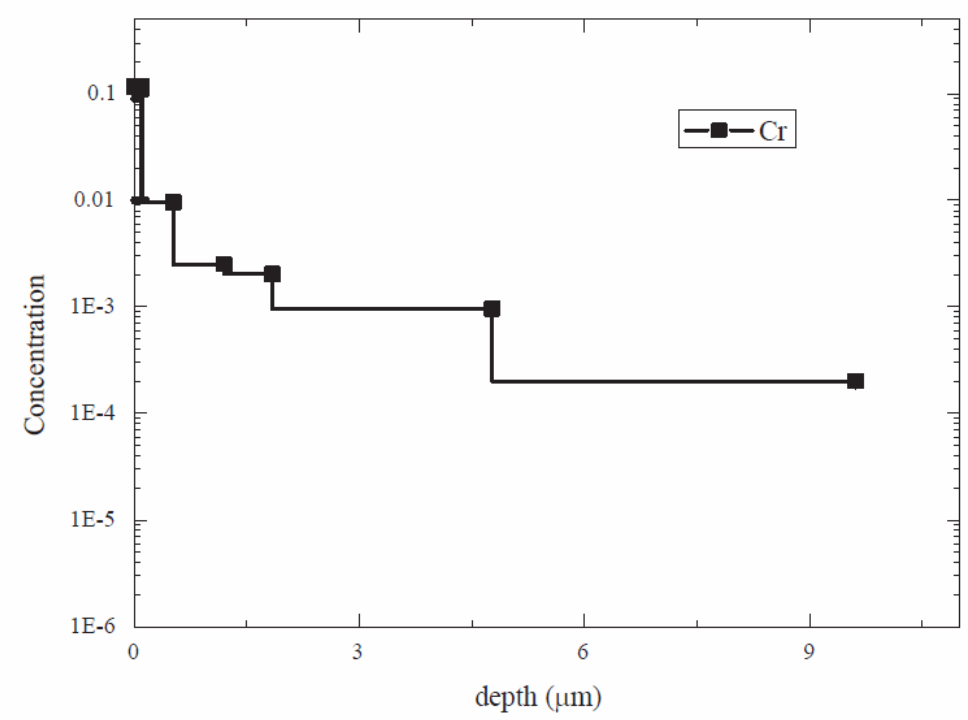

Figure 4 - Deuterium depth profile for the $\mathrm{Cr}$ samples annealed in vacuum at $873 \mathrm{~K}$ for $1 \mathrm{~h}$ and then exposed to deuterium plasma at $300 \mathrm{~K}$ to a fluence of $\mathrm{F}=6 \times 10^{24} \mathrm{Dm}^{-2}$

Slika 4 - Dubinski profil deuterijuma za uzorke Cr zagrevane u vakuumu na $873 \mathrm{~K} \mathrm{u}$ trajanju od $1 \mathrm{~h}$, a zatim ozračene plazmom deuterijuma na $300 \mathrm{~K}$ pri fluksu

$$
\mathrm{F}=6 \times 10^{24} \mathrm{Dm}^{-2}
$$

Puc. 4 - Глубинный профиль дейтерия образца $\mathrm{Cr}$, разогретый в вакууме на 873 К в течение 1 часа, а затем облученный дейтериевой плазмой на $300 К$ при фрлюенсе

$$
\mathrm{F}=6 \times 10^{24} \mathrm{Dm}^{-2}
$$

\section{Formation of Cr-hydride}

Metallic chromium metal normally has a body-centered cubic crystal structure. In the interaction with hydrogen, it forms chromium-hydride which appears in two phases: face centred cubic (fcc) $\mathrm{CrH}_{2}$, and hexagonal closed packed (hcp) $\mathrm{CrH}$, both having a high hydrogen concentration (Baranowski, 1978, pp.157-200). Both these hydrides were originally formed by the cathodic electrodeposition of Cr (Snavely,1947, pp.537-577), but one of them was later synthesized by a direct reaction with high pressure $\mathrm{H}_{2}$ gas as well (Baranowski, 1972, pp.525-527). The fcc hydride prepared this way was reported to be unstable whereas the hcp hydride could be stored indefinitely under ambient conditions. In addition, recent X-ray diffraction measurements with the use of 
synchrotron radiation (Fukai, 2002, pp.1079-1084) gave evidence of superabundant vacancy (SAV) formation, as observed in several other metal-hydrogen alloys.

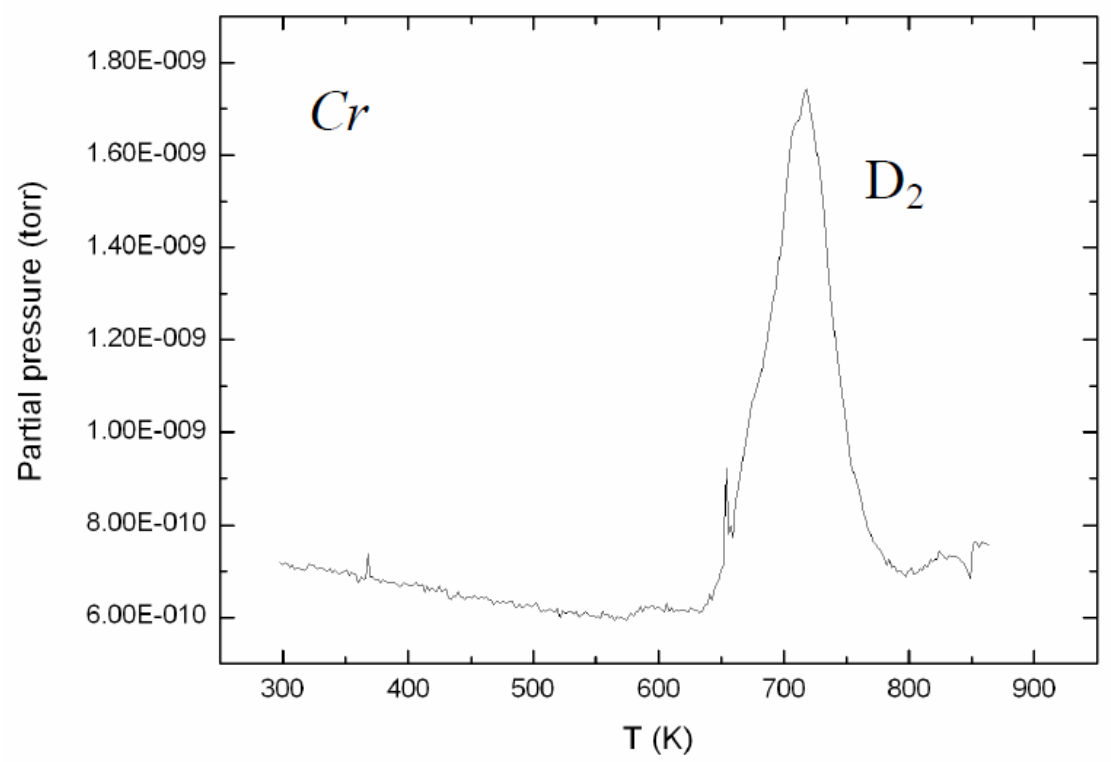

Figure 5 - Thermal desorption spectra of deuterium from $\mathrm{Cr}$ exposed to deuterium plasma at $300 \mathrm{~K}$ with a fluence of $\mathrm{F}=6 \times 10^{24} \mathrm{Dm}^{-2}$. The temperature ramp was $0.3 \mathrm{~K} / \mathrm{s}$.

Slika 5 - Spektar termalne desorpcije deuterijuma iz uzorka $\mathrm{Cr}$ izloženog plazmi deuterijuma na $300 \mathrm{~K}$ i pri fluksu $\mathrm{F}=6 \times 10^{24} \mathrm{Dm}^{-2}$. Temperaturski koraci bili su $0.3 \mathrm{~K} / \mathrm{s}$.

Рис. 5 - Спектр термальной десорбции дейтерия образца $\mathrm{Cr}$, облученного дейтериевой плазмой на $300 \mathrm{~K}$ при флюенсе $\mathrm{F}=6 \times 10^{24} \mathrm{Dm}^{-2}$. Температурный рост составлял $0,3 \mathrm{~K} / \mathrm{c}$.

We have performed TDS measurements of the Cr sample in order to reveal the presence of the hydride phase on the surface of the sample. The result of this measurement is shown in Figure 5. Deuterium desorption as $\mathrm{HD}, \mathrm{HDO}$ and $\mathrm{D}_{2} \mathrm{O}$ was not found to be significant to the total deuterium desorption. As it can be seen, deuterium release peak appears at 720 K. Using the Redhead formula (Redhead, 1962, pp.203211) for first order kinetics, which assumes a linear change of sample temperature with time $\left(T=T_{0}+\beta t\right)$ :

$$
E_{a c t}=R T_{\max }\left[\ln \left(\frac{10^{13} T_{\max }}{\beta}\right)-3.64\right]
$$


one can estimate the activation energy of the trapping site. In equation (1), $R$ is the universal gas constant, $T_{\max }$ temperature which corresponds to the desorption peak and $\beta$ is the heating rate, which in our case is $20 \mathrm{~K} / \mathrm{min}$. For our data, the formula gives the value of $2.3 \mathrm{eV}$. The $2.3 \mathrm{eV}$ trap corresponds to $D$ at the near-octahedral interstitial site, where it is believed to be associated with a vacancy. In addition, a less pronounced peak from $\mathrm{H}_{2}$ appears at $610 \mathrm{~K}$.

\section{Proton spectra of the coated samples}

In order to study the influence of the Au coated layer on the diffusion of $D$ in the samples, we rotated the samples for $180^{\circ}$ and recorded the proton spectra for the ${ }^{3} \mathrm{He}$ energy of $3.2 \mathrm{MeV}$.

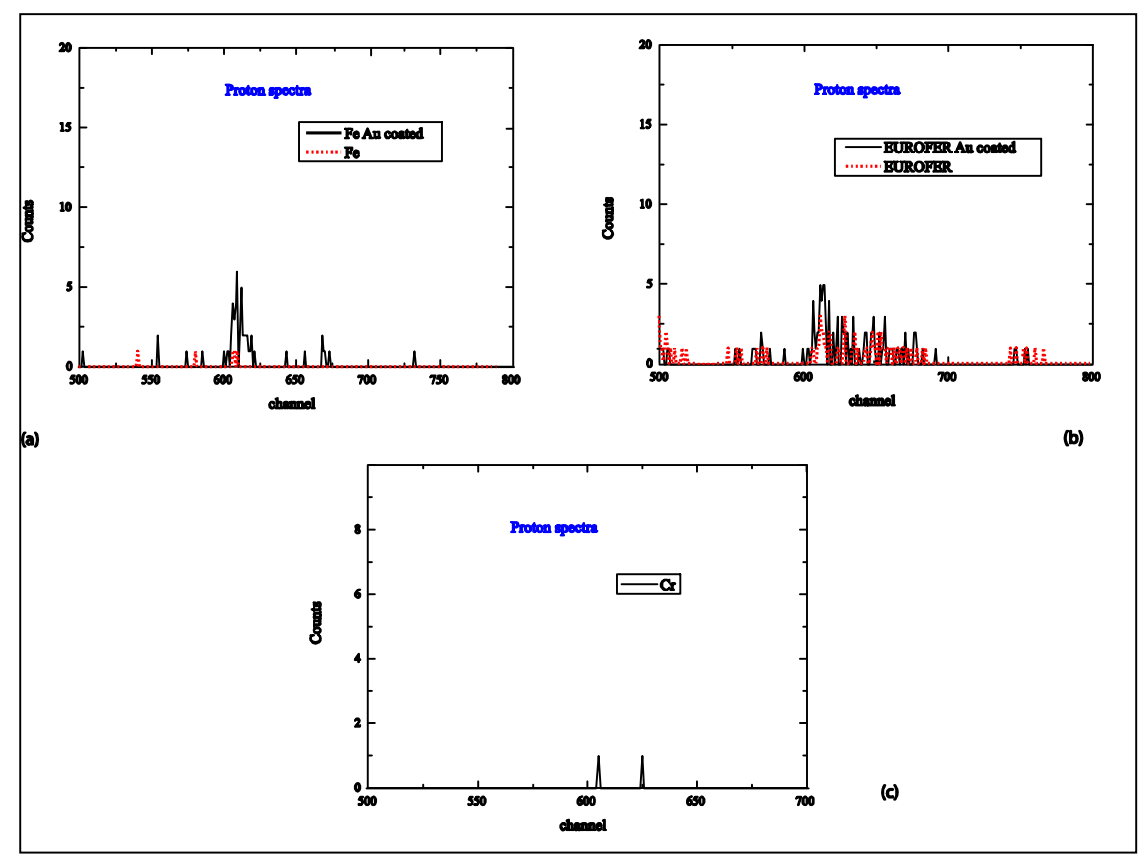

Figure 6 - Proton spectra from (a) the back side of the Fe samples, coated with a $130 \mathrm{~nm}$ thick Au layer (-) and pure (---), (b) the back side of the EUROFER samples, coated with a $130 \mathrm{~nm}$ thick Au layer (-) and pure (---), (c) back side of the Cr sample (-)

Slika 6 - Protonski spektar sa (a) zadnje strane uzorka Fe, obloženog slojem Au debljine 130 nm (-) i čistog Fe uzorka (---),

(b) zadnje strane uzorka EUROFER-a, obloženog slojem Au debljine $130 \mathrm{~nm}$ i čistog EUROFER uzorka(---), (c) sa zadnje strane uzorka $\mathrm{Cr}(-)$

Puc. 6 - Спектр протонов с (a) задней стороны образца $\mathrm{Fe}$, облицованного слоем $\mathrm{Au}$ толщиной $130 \mathrm{~nm}(-)$ и чистого Fe образца (---),(b) с задней стороны образца EUROFER, облицованного слоем Аи толщиной 130nm и чистого EUROFER образца (---), (с) с задней стороны образца $\mathrm{Cr}(-)$ 
Figures $6(\mathrm{a})$ and $6(\mathrm{~b})$ show the proton spectra for the pure and $\mathrm{Au}$ coated Fe and EUROFER samples. As it can be seen, the signal from the coated samples was considerably higher than in the case of the pure samples which indicated the diffusion and higher retention and also the reduction of losses on the back side. On the other hand, in the case of $\mathrm{Cr}$ (Figure6(c)) there was almost no signal on the back side indicating the absence of diffusion.

\section{Conclusions}

This work deals with deuterium retention in EUROFER and its main components, $\mathrm{Fe}$ and $\mathrm{Cr}$, to be used as structural materials for future fusion reactors. Two sets of measurements performed at different implantation energies of $D$ showed the following results:

${ }^{*}$ Retention in $\mathrm{Cr}$ is much higher than in $\mathrm{Fe}$ (due to the strong formation of hydride on the surface of the sample)

* Retention in EUROFER is higher than in Fe for a factor of 2

${ }^{*}$ A peculiar structure is observed in Fe and EUROFER at a depth of $\sim 4 \mu \mathrm{m}$ (similar observation by Golubeva et al. for RUSFER)

* Comparison of the Au coated samples and the pure samples showed a higher degree of diffusivity and the retention of $D$ indicating the role of $\mathrm{Au}$ as a diffusion barrier.

\section{References}

Alimov, V.Kh., Mayer, M., Roth, 2005, Differential cross-section of the D(3He,p)4He nuclear reaction and depth profiling of deuterium up to large depths, Nucl. Instr. Meth. B, 234, pp.169-175.

Baluc, N., Gelles, D.S., Jitsukawa, S., Kimura, A., Klueh, R.L., Odette, G.R., van der Schaaf, B., Yu, J., 2007, Status of reduced activation ferritic/martensitic steel development, J. Nucl. Mater., 367-370, pp.33-41.

Baranowski, B., Bojarski, K., 1972, Hydride formation at high hydrogen pressure, Rocz. Chem., 46, pp.525-527.

Baranowski, B., 1978, Hydrogen in Metals II, pp.157-200. Ed. By G. Alefeld and J. Völkl, Springer, Heidelberg, Germany.

Bohdansky, J., Wilson, Esteban, G.A., Perujo, A., Douglas, K., Sedano, L.A., 2000, Tritium diffusive transport parameters and trapping effects in the reduced activating martensitic steel OPTIFER-IVb, J. Nucl. Mater. 281, pp.34-41.

Esteban, G.A., Peña, A., Urra, I.,Legarda F., Riccardi, B., J., 2007, Hydrogen transport and trapping in EUROFER'97, J. Nucl. Mater. 367-370, pp.473-477.

Forcey, K.S., Iordanova, I., Ross, D.K., 1990, Investigation of structure dependence of diffusivity, solubility and permeability of hydrogen in hot rolled low carbon steels, Mater. Sci. Technol. 6, pp.357-363.

Fukai, Y., \& Mizutani, M. 2002. Hydrogen Absorbing Materials. Phase Diagram and Superabundant Vacancy Formation in Cr-H Alloys. Mater. Trans., 43(5), pp.1079-1084. 43(5): 1079-1084. doi:10.2320/matertrans.43.1079. 
Gasparoto, M., Andreani, R., Boccaccini, L.V., Cardella, A., Federici, G., Giancarli, L., Le Marois, G., Maisonnier, D., Malang, S., Moeslang, A., Poiterin, Y., van der Schaaf, B., 2003, Survey of in-vessel candidate materials for fusion power plants - the European materials R\&D programme, Fusion Eng. Des. 66-68, pp.129-137.

Horton, L.L., Bentley, J., Jesser, W.A., 1981, J. Nucl. Mater. 104, pp.1343-1347.

Kohyama, A.,Hishinuma, A., Gelles, D.S., Klueh, R.L., Dietz, W., Ehrlich, K., 1996, The depth distribution of displacement damage in a-iron under "triple beam" ion irradiation, J. Nucl. Mater. 233-237, pp.138-147.

Kohyama, A.,Hishinuma, A., Gelles, D.S., Klueh, R.L., Dietz, W., Ehrlich, K., 1996, Low-activation ferritic and martensitic steels for fusion application, J. Nucl. Mater. 233237, pp.138-147.

Langley, R.A., 1984, Hydrogen trapping, diffusion and recombination in austenitic stainless steels, J. Nucl. Mat. 128-129, pp.622-628.

Levchuk, D., Koch, F., Maier, H., Bolt, H., 2004, Deuterium permeation through Eurofer and a-alumina coated Eurofer, J. Nucl. Mater. 328, pp.103-106.

Lindau, R., Möslang, A., Rieth, M., Klimiankou, M., Materna-Morris, E., Alamo, A., 2005, Present development status of EUROFER and ODS-EUROFER for application in blanket concepts, Fusion Eng. Des. 75-79 pp.989-996.

Manhard, A., Schwarz-Selinger, T., Jacob, W., 2011, Quantification of the deuterium ion fluxes from a plasma source, Plasma Sources Sci. Technol. 20, pp.015-010.

Pressouyre, G.M. 1979. A classification of hydrogen traps in steel. Metallurgical Transactions A, 10(10), pp.1571-1573. 10(10): 1571-1573. doi:10.1007/BF02812023.

Redhead, P. A., 1962, Thermal desorption of gases, Vacuum 12, pp.203-211.

Schmid, K., Von Toussaint, U., 2012, Statistically sound evaluation of trace element depth profiles by ion beam analysis, Nucl. Instrum. Meth. B 281, pp.64-71.

Seeger, A., 1976, On the location of positive muons and solute hydrogen atoms in alpha iron, Phys. Lett. A 58, pp.137-138.

Snavely, C.A., 1947, Theory for the mechanism of chromium plating; A theory for the physical characteristics of chromium plate, Trans. Electrochem. Soc. 92, pp.537-577.

Spitsyn, A.V., Golubeva, A.V., Bobyr, N.P., Khripunov, B.I., Cherkez, D.I., Petrov, V.B., 2014, Retention of deuterium in damaged low-activation steel RUSFER(EK-181) after gas and plasma exposure, J. Nucl. Mat. 455, pp.561-567.

Tavassoli, A.-A.F., Alamo, A., Bedel, L., Forest, L., Gentzbittel, J.-M., Rensman J.W., 2004, Materials design data for reduced activation martensitic steel type EUROFER, J. Nucl. Mat. 329-333, pp.257-262.

Van der Schaaf, B., Tavassoli, F., Fazio, C., Rigal, E., Diegele, E., Lindau, R., LeMarois, G., 2003, The development of EUROFER reduced activation steel, Fusion Eng. Des. 69, pp.197-203.

Wedig, F., Jung, P., 1997, Effects of irradiation and implementation on permeation and diffusion of hydrogen isotopes in iron and martensitic stainless steel, J. Nucl. Mat. 245, pp.138-146.

Wilson, K.L., Baskes, M.I., 1978, Deuterium trapping in irradiated 316 stainless steel, J. Nucl. Mat. 76-77, pp.291-297.

Wilson, K.L., 1981, Hydrogen recycling properties of stainless steels, J. Nucl. Mater. 103, pp.453-463.

Yao, Z., Liu, C., Jung, P., 2005, Diffusion and permeation of deuterium in EUROFER97: Effect of Irradiation and of implanted helium, Fusion Sci. Technol. 48, pp.1285-1291.

Ziegler, J.F., 2004, 2004, SRIM 2003, Nucl. Instr. Meth. B 219-220, pp.1027-1036. 
РЕЗУЛЬТАТЫ ИССЛЕДОВАНИЯ ПО УДЕРЖАНИЮ ДЕЙТЕРИЯ И ТЕРМИЧЕСКОЙ ДЕСОРБЦИИ В УСЛОВИЯХ НИЗКОЙ АКТИВАЦИИ ФЕРРИТНО-МАРТЕНСИТНОЙ СТАЛИ ЕUROFЕR

Саня Л. Корица

Университет Унион - Никола Тесла, Факультет экологии и охраны окружающей среды, Белград, Республика Сербия

ОБЛАСТЬ: материалы

ВИД СТАТЬИ: оригинальная научная статья

ЯЗЫК СТАТЬИ: английский

\section{Резюме:}

В данной статье приведены результаты исследований по удержанию и термической десорбции дейтерия в железе, хроме и сплаве EOROFER - представляющем новейший материал для фузионного (термоядерного) реактора. Исследования показали следующие результаты:

*Удержание дейтерия в хроме намного выше, чем в железе (из-за образования гибридов хрома)

*Удержание дейтерия в сплаве EUROFER выше на фактор 2, чем в железе

*Выявлена специфриеская структура в концентрационном профиле железа и сплава EUROFER на глубине $4 \mu \mathrm{m}$

*Высокий уровень дифрфузии и удержания дейтерия свидетельствует о потенциальном применении Аи в качестве дифрфузиинного барьера в фрузионном (термоядерном) реакторе.

Ключевые слова: материалы для ядерного реактора, радиационные эффректы, дифффузия, ядерный резонанс.

REZULTATI ZADRŽAVANJA I TERMALNE DESORPCIJE

DEUTERIJUMA U EUROFER-U, NOVOJ VRSTI FERITNO-

MARTENZITNOG ČELIKA NISKE AKTIVACIJE

Sanja Lj. Korica

Univerzitet Union - Nikola Tesla, Fakultet za ekologiju i zaštitu životne sredine, Beograd, Republika Srbija

OBLAST: materijali

VRSTA ČLANKA: originalni naučni članak

JEZIK ČLANKA: engleski 


\section{Sažetak:}

$U$ ovom radu ispitivano je zadržavanje i termalna desorpcija deuterijuma u gvožđu, hromu i EOROFER-u, leguri koja se razmatra kao najnoviji materijal za buduće fuzione reaktore. Studija je pokazala sledeće rezultate:

- zadržavanje deuterijuma u hromu je mnogo veće nego u gvožđu (usled formiranja hidrida hroma),

- zadržavanje deuterijuma u EUROFER-u je za faktor 2 veće nego u gvožđu,

- primećena je specifična struktura u koncentracionom profilu gvožđa i EUROFER-a na dubini $4 \mu \mathrm{m}$,

- veliki stepen difuznosti i zadržavanja deuterijuma govore o potencijalnoj upotrebi Au kao difuzione barijere u fuzionom reaktoru.

Ključne reči: materijali za nuklearne reaktore, radijacioni efekti, difuzija, nuklearne rezonance.

Datum prijema članka / Дата получения работы / Paper received on: 21. 10. 2015.

Datum dostavljanja ispravki rukopisa / Дата получения исправленной версии работы / Manuscript corrections submitted on: 23. 11. 2015.

Datum konačnog prihvatanja članka za objavljivanje / Дата окончательного согласования работы / Paper accepted for publishing on: 25. 11. 2015.

(c) 2016 The Author. Published by Vojnotehnički glasnik / Military Technical Courier (www.vtg.mod.gov.rs, втг.мо.упр.срб). This article is an open access article distributed under the terms and conditions of the Creative Commons Attribution license (http://creativecommons.org/licenses/by/3.0/rs/).

@ 2016 Autor. Objavio Vojnotehnički glasnik / Military Technical Courier (www.vtg.mod.gov.rs, втг.мо.упр.срб). Ovo je članak otvorenog pristupa i distribuira se u skladu sa Creative Commons licencom (http://creativecommons.org/licenses/by/3.0/rs/).

(c) 2016 Автор. Опубликовано в "Военно-технический вестник / Vojnotehnički glasnik / Military Technical Courier" (www.vtg.mod.gov.rs, втг.мо.упр.срб). Данная статья в открытом доступе и распространяется в соответствии с лицензией "Creative Commons" (http://creativecommons.org/licenses/by/3.0/rs/). 